\title{
Effect of phosphorus amendments on present day plankton communities in pelagic Lake Erie
}

\author{
Steven W. Wilhelm ${ }^{1,2, *}$, Jennifer M. DeBruyn ${ }^{2,3}$, Osnat Gillor ${ }^{4,9}$, Michael R. Twiss ${ }^{5,10}$, \\ Kasey Livingston ${ }^{6}$, Richard A. Bourbonniere ${ }^{6}$, Lisa D. Pickell ${ }^{7}$, Charles G. Trick ${ }^{7}$, \\ Amanda L. Dean ${ }^{1}$, R. Michael L. McKay ${ }^{8}$ \\ ${ }^{1}$ Department of Microbiology, University of Tennessee, 1414 West Cumberland, Knoxville, Tennessee 37996, USA \\ ${ }^{2}$ Center for Environmental Biotechnology, University of Tennessee, 676 Dabney Hall, Knoxville, Tennessee 37996, USA \\ ${ }^{3}$ Department of Biology, Queen's University, Kingston, Ontario K7L 3N6, Canada \\ ${ }^{4}$ Division of Environmental Sciences, Graduate School of Applied Science and Technology, The Hebrew University of \\ Jerusalem, Jerusalem 91904, Israel \\ ${ }^{5}$ Department of Chemistry, Biology and Chemical Engineering, Ryerson Polytechnic University, Toronto, Ontario M5B 2K3, \\ Canada \\ ${ }^{6}$ National Water Research Institute, Environment Canada, 867 Lakeshore Road, PO Box 5050, Burlington, Ontario L7R 4A6, \\ Canada \\ ${ }^{7}$ Department of Biology, Biological and Geological Sciences Building, University of Western Ontario, London, \\ Ontario N6A 5B7, Canada \\ ${ }^{8}$ Department of Biological Sciences, Bowling Green State University, Bowling Green, Ohio 43403, USA
}

${ }^{9}$ Present address: Department of Ecology and Evolutionary Biology, Yale University, New Haven, Connecticut 06520-8106, USA

${ }^{10}$ Present address: Department of Biology, Clarkson University, Potsdam, New York 13699-5805, USA

\begin{abstract}
To address questions regarding the potential impact of elevated total phosphorus (TP) inputs (due to relaxed regulations of TP loading), a series of TP enrichment experiments were conducted at pelagic stations in the 3 hydrologically distinct basins of Lake Erie. Results of nutrient assimilation measurements and assays for nutrient bioavailability suggest that the chemical speciation, and not concentration, of nitrogenous compounds may influence phytoplankton community structure; this in turn may lead to the selective proliferation of cyanobacteria in the eastern basin of the lake. Assays with cyanobacterial bioluminescent reporter systems for $\mathrm{P}$ and $\mathrm{N}$ availability as well as $\mathrm{N}_{\text {tot }}: \mathrm{P}_{\text {tot }}$ assimilation ratios from on-deck incubation experiments support this work. Considered in the context of a microbial food web relative to a grazing food web, the results imply that alterations in current TP loading controls may lead to alterations in the phytoplankton community structure in the different basins of the Lake Erie system.
\end{abstract}

KEY WORDS: Nutrient loading $\cdot$ Lake Erie $\cdot$ Microbial process $\cdot$ Bioluminescent reporters

\section{INTRODUCTION}

It can be argued that the Laurentian Great Lakes represent the single most valuable resource on the North American continent. The Great Lakes Basin is home to approximately 33 million people and nearly $20 \%$ of the world's unfrozen surface freshwater (Wetzel 2001). Although the smallest in volume, Lake Erie is arguably the most anthropogenically impacted of the Laurentian Great Lakes. Lake Erie is composed of 3 distinct basins with a systematic west-to-east gradient of decreasing trophic status along the fetch of the lake (Mortimer 1987). Despite its reputation in past decades as a eutrophic lake, total phosphorus (TP) controls and enhanced benthic-filtering activity by exotic mussels of the genus Dreissena (i.e. zebra mussels) 
have resulted in a lake that now varies from mesotrophic at its western extremity to oligotrophic at the eastern end (e.g. Nicholls \& Hopkins 1993). In fact, concern has now been expressed in the popular press, as well as in intergovernmental literature, that the lake may not be sufficiently productive to support the fisheries that have developed over recent decades (GLFC 1998, IJC 1999, EPA 2000, Ludsin et al. 2001). To this end, various interests have proposed that a relaxation of TP loading controls would be desirable to maintain the current level of fishery activity. However, a more comprehensive understanding of the entire aquatic food web and its linkages to nutrient cycles under present day conditions is a prerequisite to evaluating such a proposal.

Undoubtedly a variety of factors influence the seasonal dynamic of primary production in a system as complicated as Lake Erie. One key weakness at present in the Great Lakes, and perhaps in large lakes generally, is our understanding of their microbial ecology, especially in light of the definite changes in water quality that have occurred through the past several decades (Wetzel 2000). Hutchinson (1961) pointed out that competition for nutrients in aquatic communities is strong, and that different phytoplankton communities could only co-exist in environments that lack structure or have a spatial or temporal separation in the success strategies of the community members. Although it is well established that TP loading from municipal effluents and agricultural runoff is a major factor driving production (see Elser 1999), other more subtle effects, such as the availability of trace elements (Twiss \& Campbell 1998, Twiss et al. 2000), light regime (Hyenstrand et al. 1998) and N:P ratio (Smith 1983) can influence both the productivity and speciation of phytoplankton, and these factors may not be consistent among different freshwater systems (Downing et al. 2001). All size classes of phytoplankton (pico-,

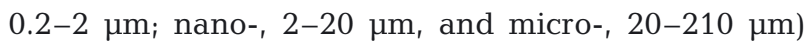
contribute substantially to primary production in Lake Erie, but the stimulation of biomass accumulation or

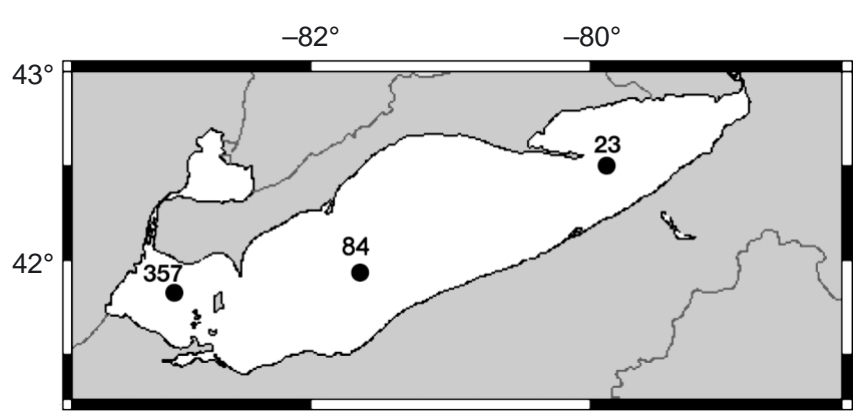

Fig. 1. Location of sampling stations in Lake Erie growth rates in each separate size class will ultimately lead to very different food webs (Kalff 2002).

Both the classical grazing and microbial food webs lead to the transfer of energy and biomass to higher trophic levels (Azam et al. 1983, Hwang \& Heath 1997). However, feed-backs in the microbial loop due to the return of organic matter to the non-particulate phase are generally thought to stimulate bacteria, and subsequently the flagellate grazers, leading to their dominance in terms of carbon biomass, whereas the production of larger phytoplankton (e.g. diatoms) support macrozooplankton grazing that leads to increased biomass in larger consumers (e.g. fish). To determine whether a relaxation of TP loading controls will result in enhanced fish populations, we first need to test the hypothesis that increased $\mathrm{PO}_{4}-\mathrm{P}$ concentrations will affect production and speciation of different sizeclasses of planktonic primary producers in the 3 separate basins of this system.

\section{MATERIALS AND METHODS}

Stations and sample collection. Three stations (23, 84, and 357; Fig. 1) were occupied in Lake Erie during the MELEE 5 (Microbial Ecology of the Lake Erie Ecosystem) cruise on the CCGS 'Limnos' in July 2001, with Stn 23 being revisited on MELEE 6 during autumnal mixing of the eastern basin in November 2001. Data from the ship's automated water column profiler were used to collect temperature profiles to model the water column structure. Surface water $(5$ to $10 \mathrm{~m}$ ) from stations was collected with a trace metal-clean pumping system comprising a Teflon double-diaphragm pneumatic pump (Husky 307, McMaster-Carr) and PFA Teflon tubing deployed off of the port side of the ship. Water was pumped directly into an on-deck Class-100 clean room facility. The system was allowed to flush for 30 to $60 \mathrm{~min}$ at each station prior to water collection. Water collected for manipulation was pre-filtered in-line through acid-cleaned $210 \mu \mathrm{m}$ screening (Nitex).

For phosphate titration experiments, water was distributed into 1.2 or 2.71 acid-cleaned polycarbonate bottles and amended with a premixed phosphate solution $\left(1: 4, \mathrm{KH}_{2} \mathrm{PO}_{4}: \mathrm{K}_{2} \mathrm{HPO}_{4}\right)$ to appropriate final concentrations. Phosphate stock solutions were passed through a cation exchange resin (Chelex-100, as per Price et al. 1989) to remove any trace metal impurities that may influence planktonic production (Twiss et al. 2000). Final phosphorus concentrations were adjusted between some experiments after consideration of the results of the previous experiments. Sealed bottles were placed in on-deck incubators maintained at ambient surface-water temperature during the period of incubation. Incubators were shielded with neutral 
density screening to reduce light levels to ca. $37 \%$ of total surface solar radiation. Triplicate bottles were filled for each concentration of 5 different amendments of $\mathrm{PO}_{4}-\mathrm{P}$, and analyzed at each station independently for all the listed parameters.

Chl a measurements, bacterial and viral enumeration. Size-fractionated chl a was determined from parallel filtration of samples collected on 0.2 and $2 \mu \mathrm{m}$ pore-size polycarbonate filters (47 mm diameter; Millipore), as well as $20 \mu \mathrm{m}$ pore-size nylon filters (47 mm diameter; Millipore) after extraction (ca. $24 \mathrm{~h}, 4^{\circ} \mathrm{C}$ ) in $90 \%$ acetone. Chl a retained on the different sizeclass filters was quantified with a Turner designs TD700 fluorometer using the non-acidification protocol (Welschmeyer 1994).

The abundance of virus-like particles was determined in glutaraldehyde-preserved (2.5\% final conc.) samples by Sybr Green 1 staining (Noble \& Fuhrman 1998). Briefly, $50 \mu \mathrm{l}$ water samples were diluted to $800 \mu \mathrm{l}$ with virus-free (30 kDa filtered) water. Viruses were collected onto $0.02 \mu \mathrm{m}$ pore-size ceramic filters (Anodisc 25, Whatman) and, after Sybr Green staining, were enumerated with a Leica DMRXA epifluorescent microscope. Bacteria were enumerated in acridine orange-treated water samples $(2 \mathrm{ml})$ collected on $0.2 \mu \mathrm{m}$ pore-size black polycarbonate filters (Millipore GTBP) (Hobbie et al. 1977).

Flow cytometry. Phytoplankton communities were analyzed by flow cytometry immediately upon sampling and without initial preservation (Becton Dickinson FACSCalibur flow cytometer equipped with a $10 \mathrm{~W}$ argon laser and CellQuest analysis software). To normalize the spectrum of cell responses, the software was calibrated using 1-, 2-, 4-, 10- and 16- $\mathrm{mm}$ nonfluorescent beads for cell-size based calibration and $10-\mu \mathrm{m}$ fluorescent beads to standardize fluorescence corresponding to chlorophyll and phycocyanin. For each bottle, triplicate measurements were made and averaged, and these averages used as the means for the individual bottles.

Nutrient measurements. Nutrient concentrations $\left(\mathrm{NO}_{3}+\mathrm{NO}_{2}, \mathrm{NO}_{2}\right.$, total dissolved $[<0.45 \mu \mathrm{m}]$ nitrogen, total dissolved $[<0.45 \mu \mathrm{m}]$ phosphorus) were measured in whole water samples from each station as well as in the incubation bottles from Stns 23 and 84 at the end of the experiments $(72 \mathrm{~h})$. Measurements of nutrient concentration were made at the National Laboratory for Environmental Testing (Environment Canada) using standardized techniques (NLET 1994). Sample pre-processing (filtration) was completed on the ship. Samples were stored at $-20^{\circ} \mathrm{C}$ prior to analysis.

$\mathbf{N}$ and $\mathbf{P}$ bioluminescent reporter assay. Phosphate bioavailability was assessed by using a recently developed lux-based bioluminescent reporter Syne- chococcus PCC 7942 strain APL (Schreiter et al. 2001, Gillor et al. 2002). Water samples taken directly from Stns 23, 84 and 357 were filtered $(0.4 \mu \mathrm{m}$ pore size polycarbonate filters) and immediately frozen $\left(-20^{\circ} \mathrm{C}\right)$ on board the ship. In the laboratory, duplicate $10 \mathrm{ml}$ aliquots were transferred to sterile flasks and amended with the nutrients (except for P) from BG-11 cyanobacterial growth medium $\left(\mathrm{K}_{2} \mathrm{HPO}_{4}\right.$ was re-

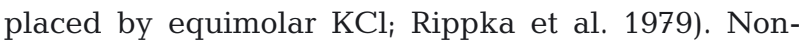
luminescent P-replete APL reporter cells, cultured in a P-reduced BG-11 medium (containing $46 \mu \mathrm{M}$ $\mathrm{K}_{2} \mathrm{HPO}_{4}$ ) were harvested by centrifugation, washed twice using P-free medium, and used to inoculate the water samples to an $\mathrm{OD}_{750}$ of approximately 0.1. Cells suspended in P-replete or P-free BG-11 medium served as negative and positive controls, respectively. The samples were incubated at $30^{\circ} \mathrm{C}$ with continuous shaking (125 rpm) under constant illumination using fluorescent lamps (50 $\mu \mathrm{mol}$ photons $\left.\mathrm{m}^{-2} \mathrm{~s}^{-1}\right)$. After $25 \mathrm{~h}$, the cells were removed from their growth flasks and diluted to a uniform cell density. Sub-samples $(1 \mathrm{ml})$ of the cell suspension were transferred in duplicate to assay tubes and the reaction was started by addition of $1 \mathrm{ml}$ P-free BG-11 containing the substrate nonyl aldehyde (Aldrich) and the detergent Igepal CA-630 (Sigma) to final concentrations of 0.002 and $0.005 \%(\mathrm{v} / \mathrm{v})$, respectively. Following an 8 min incubation, bioluminescence was measured using a portable luminometer (Femtomaster FB14, Zylux). To estimate the amount of bioavailable P ( $\mu \mathrm{g}$ $\mathrm{l}^{-1}$ ) in samples, the response of the reporter cells was calibrated to a standard curve as described in Gillor et al. (2002).

The biological availability of $\mathrm{N}$ was assessed by monitoring the bioluminescence of Synechococcus reporter strain GSL (Gillor et al. 2003). This reporter contains the promoter region of the gene encoding glutamine synthetase ( $g \ln \mathrm{A})$, an essential gene for $\mathrm{N}$ assimilation by photoautotrophs. Water samples were treated as described for the $\mathrm{P}$ reporter and $10 \mathrm{ml}$ aliquots were transferred to sterile flasks and amended with $\mathrm{N}$-free $\mathrm{BG}-11$ ingredients $\left(\mathrm{NaNO}_{3}\right.$ and $\mathrm{FeNH}\left(\mathrm{SO}_{4}\right)_{2}$ were replaced by equimolar $\mathrm{NaCl}$ and $\mathrm{FeCl}_{3}$, respectively). Non-luminescent N-replete GSL reporter cells cultured in BG-11 were harvested by centrifugation, washed twice with $\mathrm{N}$-free medium and used to inoculate the water samples to an $\mathrm{OD}_{750}$ of approximately 0.25 . Cells suspended in complete or N-free BG-11 media served as negative and positive controls, respectively. The samples were incubated for $20 \mathrm{~h}$ and bioluminescence was measured as described above. Standard curves for light emitted by the GSL-reporter strain were generated to estimate bioavailable- $\mathrm{N}$ using a range of $\mathrm{NH}_{4}{ }^{+}$concentrations. 


\section{RESULTS}

\section{Station characteristics}

The water column was thermally stratified at Stns 84 and 23 during the July visit and was isothermal at Stn 357 . The water column was isothermal at Stn 23 during the November cruise, which represented the seasonal turnover of this warm monomictic lake. Total phytoplankton biomass, as estimated from the $>0.2 \mu \mathrm{m}$ retained chl a concentration, was approximately 5 -fold higher in the western basin relative to the central and eastern basins during the summer sampling period (Table 1), whereas bacterial and viral abundances at Stns 23 and 84 were similar. Whole water samples for bacterial and viral enumerations at Stn 357 were not determined during this study. However, estimates of abundance from a previous study (ca. $3.2 \times 10^{6}$ bacteria $\mathrm{ml}^{-1}$, ca. $3.7 \times 10^{7}$ viruses $\mathrm{ml}^{-1}$, Wilhelm $\&$ Smith 2000 ) suggest populations of the same magnitude as those measured at the central and eastern basin sites during this work. During the November cruise at Stn 23, bacterial abundance was only ca. $10 \%$ of the July estimates, while the viral abundance was reduced to $50 \%$ of the July estimates.

Concentrations of $\mathrm{N}$ and $\mathrm{P}$ at the 3 stations were similar during the July cruise, with molar $\mathrm{N}_{\text {tot }}: \mathrm{P}_{\text {tot }}$ ratios ranging from 125 to 156. Concentrations of $\mathrm{NH}_{3}$ in surface waters at 2 of the stations were ca. $7.5 \mu^{-1} \mathrm{l}^{-1}(\operatorname{Stn} 23)$ and $11.1 \mu^{-1} \mathrm{l}^{-1}$ (Stn 84), with concentrations not determined at Stn 357. Considering this in light of Guilford \& Heckys' (2000) definition of P-deficiency in freshwater systems $\left(\mathrm{N}_{\text {tot }}: \mathrm{P}_{\text {tot }}\right.$ molar ratio $\left.>22\right)$, these measurements of $\mathrm{N}_{\text {tot }}: \mathrm{P}_{\text {tot }}$ suggest that primary production across all 3 basins was P-limited. At Stn 23 during the November cruise, the molar $\mathrm{N}_{\text {tot }}: \mathrm{P}_{\text {tot }}$ ratio in the water column was reduced to 80.

\section{Effects of $\mathrm{PO}_{4}-\mathrm{P}$ amendments on primary producers, bacteria and viruses}

The most surprising results of this study were the responses of different size-class phytoplankton to $\mathrm{PO}_{4}$ $\mathrm{P}$ additions. In the eastern basin, $\mathrm{PO}_{4}-\mathrm{P}$ additions lead to substantial increases in the picoplankton community chlorophyll concentrations relative to the other size classes, with some increase in the nanoplankton (Fig. 2). In contrast, additions of small concentrations at Stn 84 led to increases in the picoplankton community that were matched by increases in the nanoplankton upon subsequent increases in $\mathrm{PO}_{4}$-P added. At Stn 357 , chl a concentrations in all size classes increased linearly across all concentrations of $\mathrm{PO}_{4}$-P added $(\mu \mathrm{g}$ chl a $0.2-2.0=6.76 \times\left[\mathrm{PO}_{4} \mu \mathrm{M}\right], \mathrm{r}^{2}=0.94 ; \mu \mathrm{g}$ chl a $2.0-20=$ $3.47 \times\left[\mathrm{PO}_{4} \mu \mathrm{M}\right], \mathrm{r}^{2}=0.98 ; \mu \mathrm{g}$ chl $a>20=2.1 \times\left[\mathrm{PO}_{4}\right.$ $\left.\mu \mathrm{M}], \mathrm{r}^{2}=0.78\right)$. While these results confirm that all size classes of primary producers in the western basin were P-limited, they most clearly demonstrated that the major group responding to $\mathrm{PO}_{4}$-P additions during the July sampling was the microplankton. Biomass accumulation was not stimulated at Stn 23 during either of the 2 independent $\mathrm{PO}_{4}$-P amendment experiments that were carried out during the November research cruise (data not shown).

Concomitant with the eutrophication of the Great Lakes during the last century has been an increase in cyanobacterial populations (Munawar \& Munawar 1996, Elser 1999). Flow cytometric analysis of samples collected from the incubation bottles demonstrated that picoplanktonic cyanobacteria positively responded to $\mathrm{PO}_{4}$-P addition by increasing their abundance relative to unamended control treatments (Fig. 3). Populations
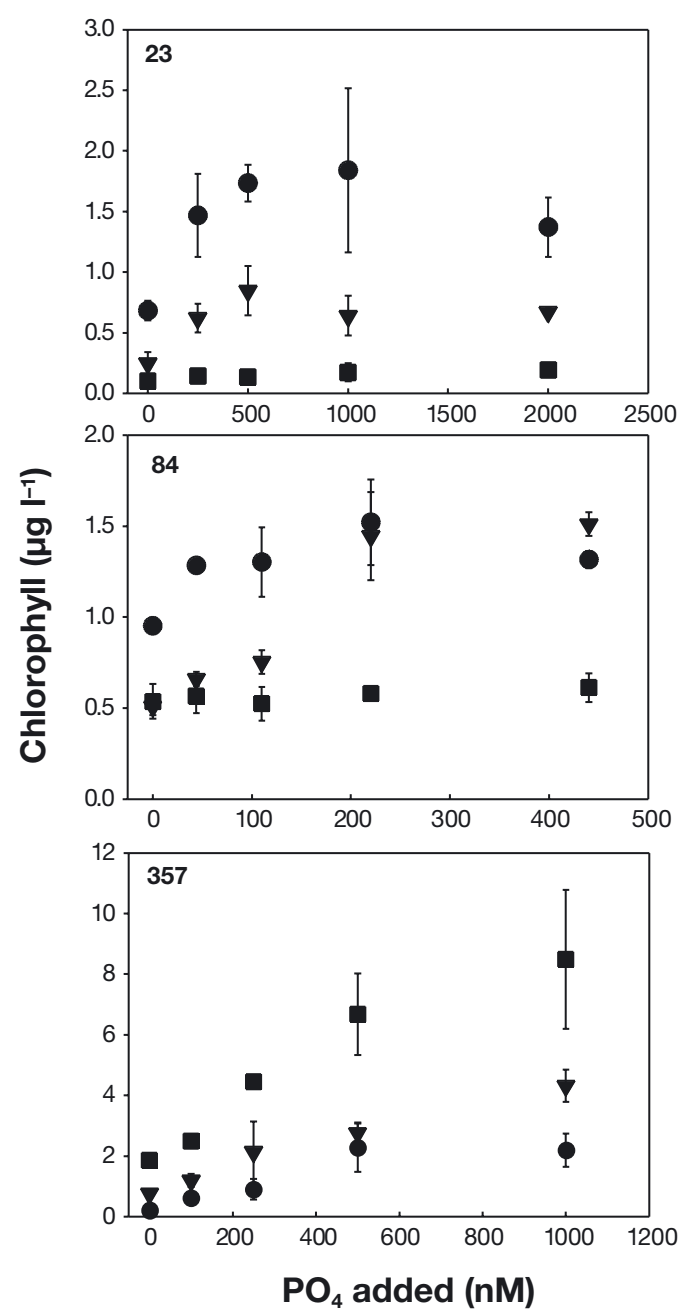

Fig. 2. Size-fractionated chl a $( \pm \mathrm{SD}, \mathrm{n}=3)$ from $\mathrm{PO}_{4}-\mathrm{P}$ enrichment experiments in Lake Erie at Stns 23, 84 and 357 in July 2001. All samples were taken after $72 \mathrm{~h}$ of incubation, as de-

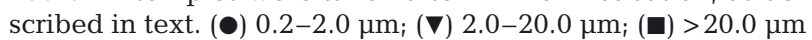


Table 1. Station characteristics and water quality at Lake Erie sampling sites. For samples with error estimates, it is given as \pm range of duplicate measurements. ND: not determined

\begin{tabular}{|c|c|c|c|c|}
\hline & Stn 357 & Stn 84 & Stn 23 & Stn 23 \\
\hline Sampling date (mm/dd/yy) & 06/16/01 & 06/15/01 & 06/10/01 & $11 / 05 / 01$ \\
\hline Temperature $\left({ }^{\circ} \mathrm{C}\right)$ & 21.9 & 19.0 & 19.9 & 12.0 \\
\hline Maximum depth, $Z_{\max }(\mathrm{m})$ & 10.4 & 24.5 & 61.5 & 61.5 \\
\hline Thermocline (m) & Isothermal & $18-21$ & $13-14$ & Isothermal \\
\hline \multicolumn{5}{|l|}{$\operatorname{Chl~a~}\left(\mu \mathrm{g} \mathrm{l}^{-1}\right)$} \\
\hline$>0.2 \mu \mathrm{m}$ & $7.90( \pm 0.09)$ & $1.55( \pm 0.04)$ & 1.59 (ND) & $0.26( \pm 0.00)$ \\
\hline$>2 \mu \mathrm{m}$ & $3.37( \pm 0.13)$ & $0.80( \pm 0.06)$ & 0.69 (ND) & $0.25( \pm 0.01)$ \\
\hline$>20 \mu \mathrm{m}$ & $1.85( \pm 0.01)$ & $0.41( \pm 0.05)$ & 0.07 (ND) & $0.20( \pm 0.01)$ \\
\hline Bacteria $\left(\times 10^{6} \mathrm{ml}^{-1}\right)$ & ND & $3.1( \pm 0.7)$ & $3.8( \pm 0.6)$ & $0.3( \pm 0.1)$ \\
\hline Viruses $\left(\times 10^{7} \mathrm{ml}^{-1}\right)$ & ND & $3.7( \pm 0.9)$ & $4.1( \pm 0.3)$ & $2.0( \pm 0.1)$ \\
\hline \multicolumn{5}{|l|}{ Nutrients (dissolved) } \\
\hline $\mathrm{NO}_{3}+\mathrm{NO}_{2}\left(\mathrm{mg} \mathrm{l}^{-1}\right)$ & 0.289 & 0.144 & 0.180 & 0.223 \\
\hline $\mathrm{NO}_{2}\left(\mathrm{mg} \mathrm{l}^{-1}\right)$ & 0.007 & 0.008 & 0.006 & 0.075 \\
\hline Inferred $\mathrm{NO}_{3}\left(\mathrm{mg} \mathrm{l}^{-1}\right)$ & 0.282 & 0.136 & 0.174 & 0.148 \\
\hline $\operatorname{SRP}\left(\mu \mathrm{g} \mathrm{l}^{-1}\right)$ & ND & $1.23( \pm 0.00)$ & $1.13( \pm 0.81)$ & $5.70(0.28)$ \\
\hline Total P $(\mu \mathrm{M})$ & 0.27 (ND) & $0.15( \pm 0.02)$ & $0.18( \pm 0.01)$ & $0.38( \pm 0.05)$ \\
\hline Total N $(\mu \mathrm{M})$ & 33.6 (ND) & $23.5( \pm 0.00)$ & $25.7( \pm 0.71)$ & $30.7( \pm 0.00)$ \\
\hline Molar N:P ratio & 124.0 (ND) & $153.6( \pm 20.7)$ & $144.4( \pm 1.5)$ & $80.6( \pm 10.2)$ \\
\hline
\end{tabular}
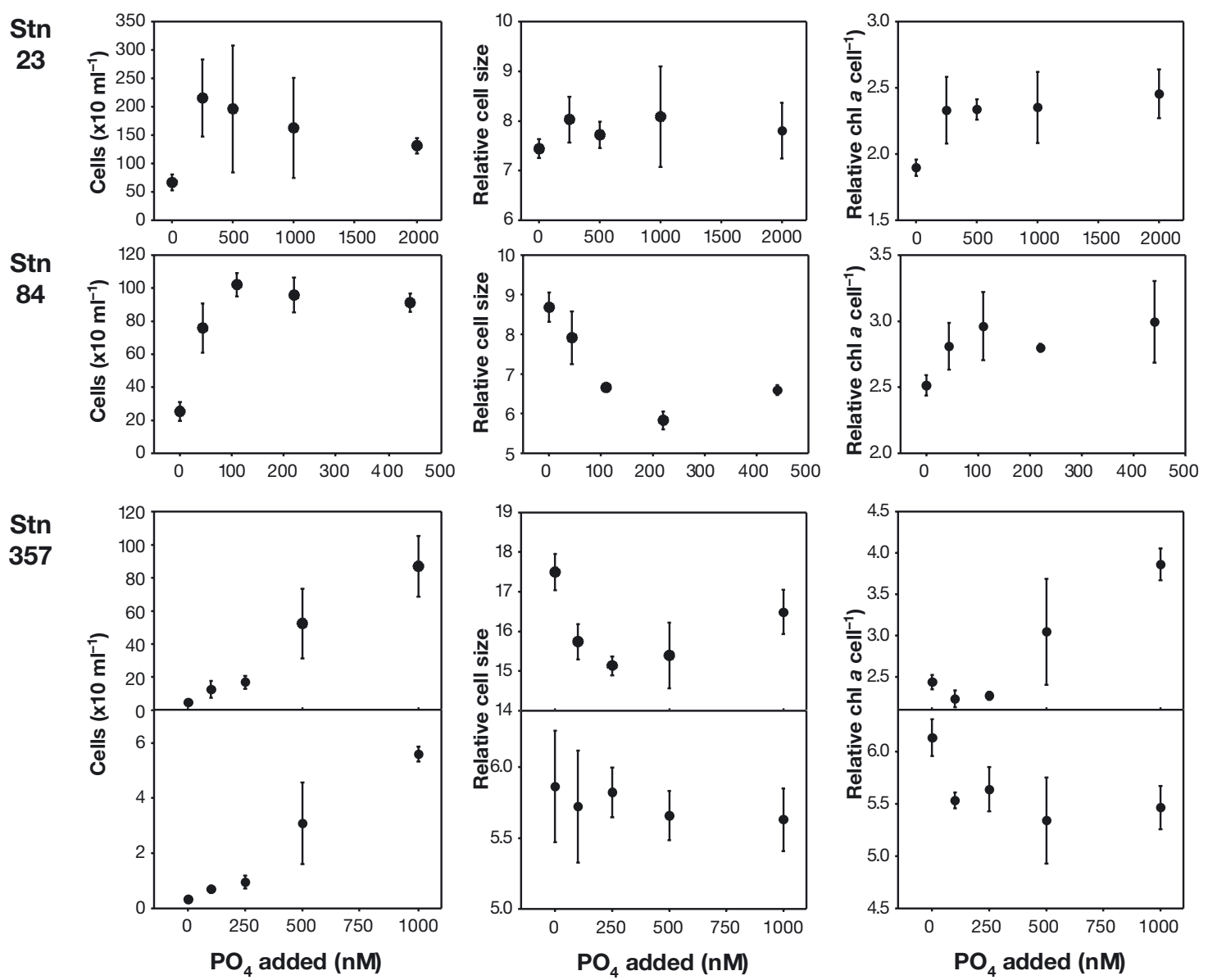

Fig. 3. Cyanobacterial abundance, relative size and relative chl a $\left(\right.$ cell $\left.^{-1}\right)$ in $\mathrm{PO}_{4}$ titration experiments conducted at Stns 23,84 and 357 in July $2001( \pm$ SD, $n=3)$. For Stn 357, the 2 distinct populations of cyanobacteria are presented separately. Units for cell size and fluorescence are the relative units provided from the instrument 
at Stns 23 and 84 as well as 2 separate populations at Stn 357 (distinguishable by differences in both fluorescence signature and size) all increased in abundance with added $\mathrm{PO}_{4}-\mathrm{P}$. Flow cytometry also identified changes in the relative size of cells (a function of backscattering light) with added $\mathrm{PO}_{4}-\mathrm{P}$ during July. Most notably, populations in experimental treatments from Stn 84 and the large-size cyanobacterial population at Stn 357 displayed a decreased cell-size upon the addition of $\mathrm{PO}_{4}-\mathrm{P}$ relative to the unamended control.

Analysis of fluorescence data from the flow cytometer demonstrated noticeable changes in the relative cell specific chl a content between treatments. Relative changes in chl a cell ${ }^{-1}$ are commonly documented in phytoplankton responding to an alleviation of nutrient limitation (Geider et al. 1993). In the current study, populations at all 3 stations (with the exception of the picoplankton at Stn 357) demonstrated increases in relative chl a cell ${ }^{-1}$ in the $\mathrm{PO}_{4}-\mathrm{P}$ treatment relative to the unamended controls. These results confirm that cyanobacterial physiology responded rapidly to added $\mathrm{PO}_{4}$-P. It follows that ecosystem-wide changes could ultimately support the onset of algal and cyanobacterial blooms in this system, such as the documented bloom of Microcystis in the western basin of Lake Erie in 1995 (Brittain et al. 2000, Jacoby et al. 2000).

Direct counts of bacteria demonstrated no significant increase in abundance in the $\mathrm{PO}_{4}$-P treatments relative to the unamended control (Fig. 4). Viral abundance in the incubations, however, did increase in treatments from 2 of the stations (357 and 84) relative to the unamended control.

\section{Nutrient assimilation in amendments}

As predicted, the $\mathrm{N}_{\text {tot }}: \mathrm{P}_{\text {tot }}$ drawdown ratio at Stn 84 for the lowest concentration of phosphate enrichment (44 nM PO $4-\mathrm{P})$ remained typical of a P-limited environment (Fig. 5). Higher concentrations of added $\mathrm{PO}_{4}-\mathrm{P}$ (220 and $440 \mathrm{nM}$ ) ultimately led to drawdown ratios suggestive of N-limitation, whereas the 110 nM PO4-P treatment provided near Redfield values of the N:P ratio. Likewise, results from Stn 23 demonstrated that plankton were driven into an N-limited state by addi-

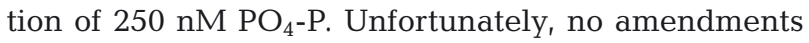
of water sampled from Stn 23 were made during the current study at lower concentrations of $\mathrm{PO}_{4}$-P. However, the extremely low $\mathrm{N}_{\text {tot }}: \mathrm{P}_{\text {tot }}$ drawdown in these treatments (ca. 3 in the $250 \mathrm{nM}$ treatment) suggests that the $\mathrm{N}$ that was biologically available to the plankton community was significantly lower than the total $\mathrm{N}$. This conclusion is supported by the bioluminescent reporter data (below). As a result, augmentation of the $\mathrm{PO}_{4}$-P concentration might conceivably lead to populations of coccoid or filamentous cyanobacteria capable of fixing $\mathrm{N}_{2}$ (Howarth et al. 1998a,b). This may in part explain the proliferation of phytoplankton biomass in

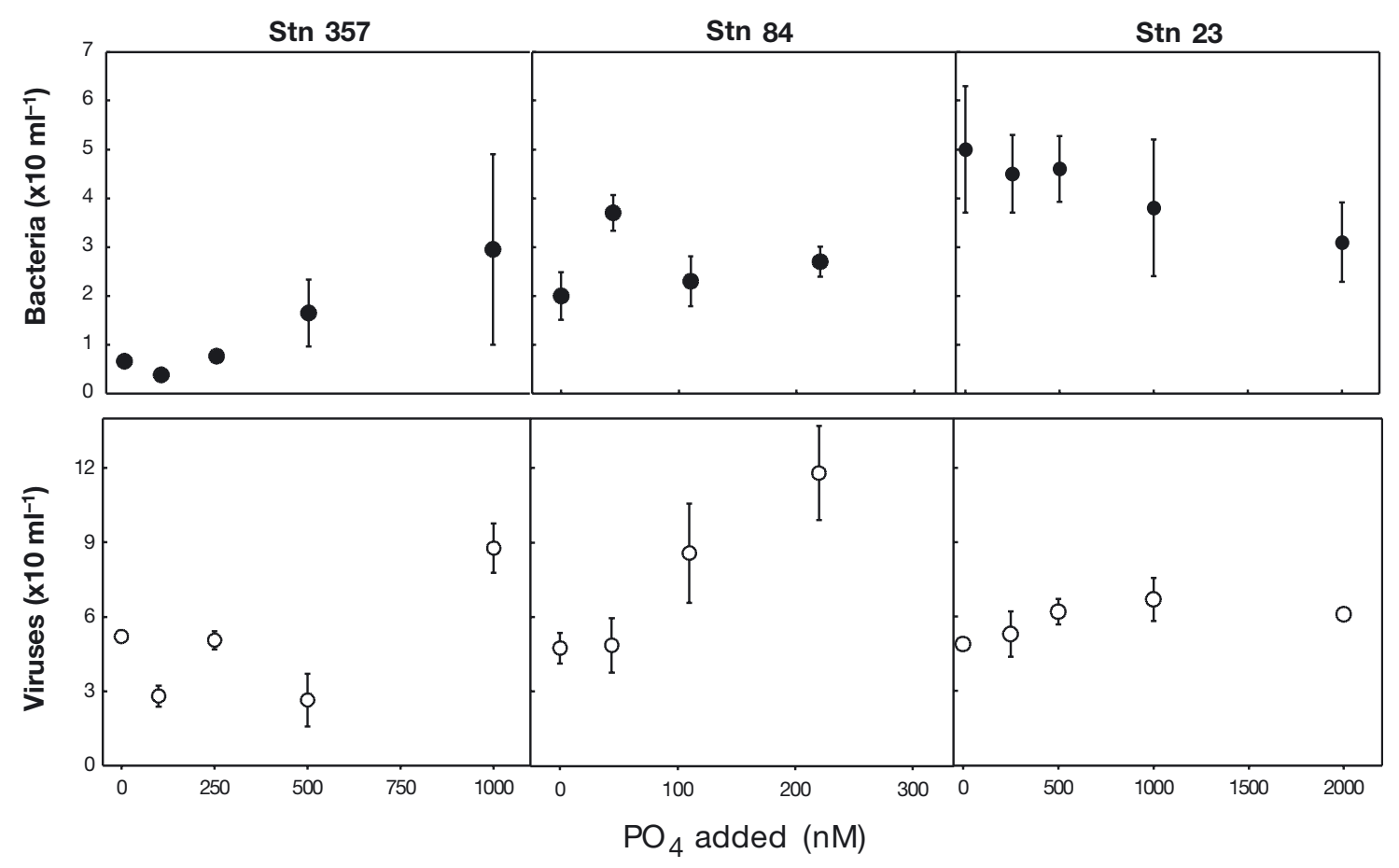

Fig. 4. Abundance of heterotrophic bacteria and viruses after $72 \mathrm{~h}$ of incubation $( \pm \mathrm{SD}, \mathrm{n}=3)$ 
the $0.2-2 \mu \mathrm{m}$ size class, which would be dominated by coccoid cyanobacteria in a sub-Redfield N:P environment (Tilman et al. 1982, Smith 1983, Elser 1999).

\section{Bioluminescent reporters of ambient $P$ and $\mathbf{N}$ concentrations}

The response of the cyanobacterial bioluminescent reporters for $\mathrm{P}$ and $\mathrm{N}$ availability in field samples collected in July further suggest that concentrations of bioavailable $\mathrm{N}$ were surprisingly low at Stn 23 (Fig. 6). Analysis of lake water sampled from both 10 and $25 \mathrm{~m}$ at Stn 23 demonstrated a significant signal (75\% of maximum response) from the Synechococcus GSL-reporter strain, implying a low concentration of bioavailable $\mathrm{N}$ at this station compared to samples collected from the central and western basin stations where luminescence was reduced. Assuming that transcription of $g \ln \mathrm{A}$ is an indication of cells responding to low levels of $\mathrm{N}$-availability (Cohen-Kupiec et al. 1993), these results support the nutrient drawdown data and suggest that, although the concentration of total $\mathrm{N}$ in the eastern basin was relatively high, the biological availability of that $\mathrm{N}$ was lower. The Synechococcus APL-reporter also reported significant levels of Pdeprivation in surface waters at both Stns 23 and 84, indicating that concentrations of bioavailable $\mathrm{P}$ were low in these surface waters. Some phosphorus in the water column is more readily available: the Synechococcus APL-reporter demonstrated that $\mathrm{P}$ was bioavailable (i.e. a quenched luminescent response) below the thermocline at stations sampled in the central and eastern basins during the summer sampling.

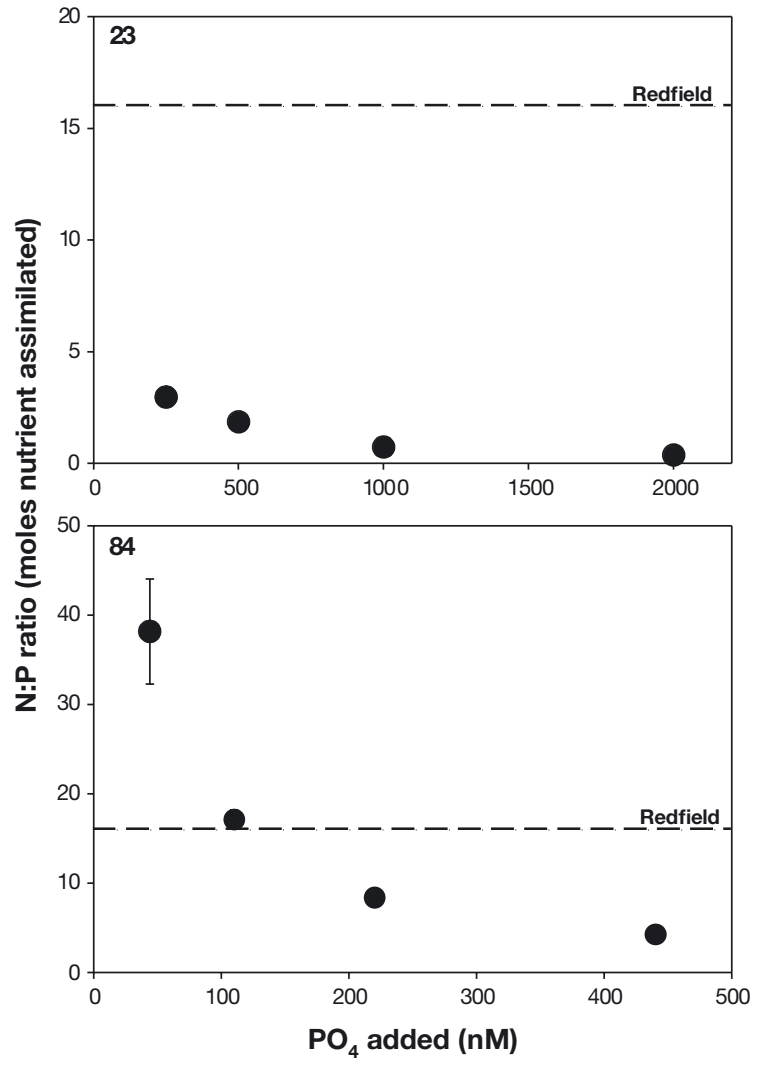

Fig. 5. Nutrient drawdown ratios for $\mathrm{PO}_{4}-\mathrm{P}$ additions at Stns 23 and $84( \pm \mathrm{SD}, \mathrm{n}=3)$. Where not shown, error bars are smaller than the symbol). Nutrient draw-downs were determined for the added $\mathrm{PO}_{4}-\mathrm{P}$ only (as described in text). The dashed lines at N:P ratios of 16:1 represent the Redfield values for use by phytoplankton (Redfield et al. 1963). Values above this line are indicative of a P-limited nutrient assimilation, while values below this line are indicative of $\mathrm{N}$-limited nutrient assimilation

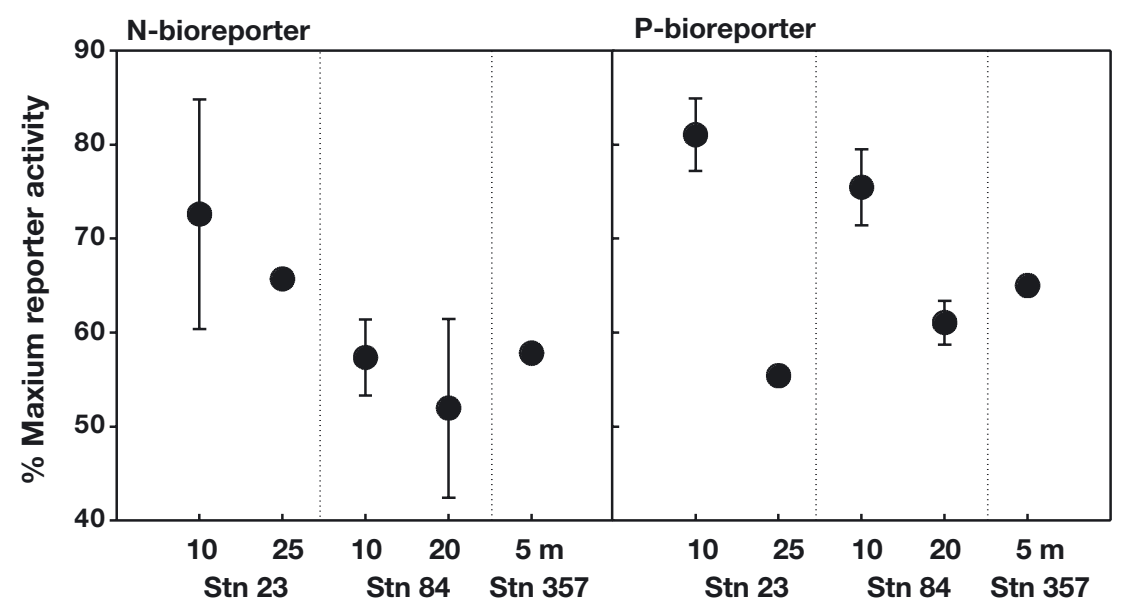

Fig. 6. Bioluminescent reporter responses to the availability of $\mathrm{N}$ and $\mathrm{P}$ from whole water samples collected in July $2001( \pm \mathrm{SD}, \mathrm{n}=$ 3). Bioluminescent data were reported as a function of maximum expression from N-or P-limited controls. Results indicate that $\mathrm{N}$ availability was relatively low throughout the water column at Stn 23 in July 2001, but high at Stns 84 and 357 during this same time. Results also indicate that $\mathrm{PO}_{4}$-P bioavailability in surface waters of Stns 23 and 84 during this period was low, but higher at depth 


\section{DISCUSSION}

The conclusions drawn from these experiments provide significant insights into the structure of the microbial community as well as microbial interactions and carbon flow in pelagic Lake Erie and other large lacustrine P-limited systems. The data support the hypotheses that increases in $\mathrm{PO}_{4}$-P would influence planktonic biomass, alter size class compositions and influence the abundance of bacterioplankton. The results also suggest that the phytoplankton community structure (based on size-class distributions) is strongly influenced by the biological availability (and not total concentration) of nitrogen in this system. The same conclusion is independently achieved from the observed chl a size class distributions/nutrient drawdown experiments and the bioluminescence reporter assays.

\section{Influence of $\mathrm{PO}_{4}-\mathrm{P}$ additions on primary producers}

Significant increases in phytoplankton biomass were observed in the $\mathrm{PO}_{4}$-P enrichments, with chl a concentrations increasing more than 3-fold for some size fractions in this study. The novel aspect of this study is the observation of a proliferation of phytoplankton from different size classes in the 3 separate basins of the lake. In the western basin, phytoplankton biomass in the largest size class (the microplankton) was preferentially enhanced in the $\mathrm{PO}_{4}-\mathrm{P}$ enrichments, whereas the smallest size class (the picoplankton) proliferated in the eastern basin.

One interesting observation from this study is the decrease in cell size of the cyanobacterial population at Stn 84 , and of one of the populations at Stn 357. It appears that upon addition of the limiting substrate (in this case $\mathrm{PO}_{4}-\mathrm{P}$ ), cells were able to take immediate advantage of the newly available nutrient by dividing and commencing rapid growth. Cell-size reduction is thought to provide the advantage of allowing a population to increase their surface-to-volume ratio to enhance diffusion-mediated scavenging of nutrients. In theory, increasing the amount of cell-surface nutrient-uptake porters (a function of the total surface area), with respect to the requirement of the cell for the nutrient element (an approximate function of the cell volume in prokaryotes and many eukaryotic plankton), will serve to increase the flux of exogenous nutrients into cellular protoplasm over and above such adaptations as inducing highaffinity uptake systems (Wagner \& Falkner 2001). By doing this, individual cells can increase their nutrient scavenging ability without expending energy by producing more transport systems (Chisholm 1992). While miniaturization is often thought to be a response of cells to nutrient limitation (Morita 1975), it is plausible that this may also provide cells with an opportunity to capitalize on episodic bursts of nutrient availability.

\section{Effect of $\mathrm{PO}_{4}-\mathrm{P}$ enrichment on bacteria and viruses}

Most studies of nutrient dynamics in freshwater systems focus on the components of the 'classical grazing food-web'; the base of which is the phytoplankton that fix carbon dioxide into biomass for transfer through primary consumers into higher trophic levels. Given the obvious importance of the microbial food web in the pelagic locations examined during this study (see Hwang \& Heath 1997), and the potential impacts of nutrient supplies on bacterioplankton proliferation (Morris \& Lewis 1992, Vadstein 1998), we felt it pertinent to examine the effects of $\mathrm{PO}_{4}-\mathrm{P}$ additions on bacterial and viral abundance. Direct counts of bacteria demonstrated no difference in population abundance of the treatments and controls at Stns 84 and 23, although there was an increase with added $\mathrm{PO}_{4}-\mathrm{P}$ at Stn 357 . The lack of change in bacterial abundance at Stns 84 and 23 was a surprising result as we hypothesized that increased primary production would lead to increased bacterial production (and thus abundance). The increase in viral particle abundance observed in the experimental treatments following $\mathrm{PO}_{4}-\mathrm{P}$ addition, however, is not surprising. It has been reported that viruses are responsible for ca. 12 to $23 \%$ of the bacterial mortality in the Western basin of Lake Erie under ambient conditions (Wilhelm \& Smith 2000), and an increase in bacterial cell density should result in a concomitant increase in infection frequency and viral particle abundance (Murray \& Jackson 1992). Increased grazing by microzooplankton (Hwang \& Heath 1997) could also increase bacterial mortality. Given the demonstrated importance of viruses in aquatic biogeochemical cycles (Fuhrman 1999, Wilhelm \& Suttle 1999), understanding this type of feedback in the food web is critical to predicting the effects of altered nutrient dynamics on planktonic community structure.

\section{Assessing nutrient availability in Lake Erie using bioluminescent reporter strains}

Cells of the Synechococcus APL-reporter strain emit light in an inverse proportion to phosphate concentrations in the medium (Gillor et al. 2002). A calibration curve that allows a sensitive visualization of 'available $\mathrm{P}^{\prime}$ in terms of luminescence intensity is represented by the following equation:

$$
y=-10.05 \ln (\mathrm{xP})+48.006, \mathrm{r}^{2}=0.99
$$

where $y$ equals light output (as \% of maximum luminescence obtained in a P-free medium), and $\mathrm{xP}$ corre- 
sponds to initial $\mathrm{PO}_{4}-\mathrm{P}$ concentration, in $\mu \mathrm{g} \mathrm{P}^{-1}$. Using this relationship, estimates of biologically available $\mathrm{P}$ were $0.050 \mathrm{\mu g} \mathrm{l}^{-1}$ (Stn 23), $0.049 \mathrm{\mu g} \mathrm{l}^{-1}$ (Stn 84) and $0.185 \mu \mathrm{g} \mathrm{l}^{-1}$ (Stn 357). These amounts correspond to ca. 1.0 to $2.2 \%$ of the total P measured in the system, and 3.9 to $4.4 \%$ of the SRP measured at Stns 84 and 23.

The light emitted by the Synechococcus GSLreporter strain in response to ambient ammonium concentrations yields a similar calibration curve that allows an estimation of 'available $\mathrm{N}^{\prime}$ using the following equation:

$$
y=-10.89 \ln (x \mathrm{~N})+46.155, \mathrm{r}^{2}=0.96
$$

where $y$ corresponds to light output (as \% of maximum luminescence obtained at $\mathrm{N}$ free medium) and $x \mathrm{~N}$ to initial $\mathrm{NH}^{4+}$ concentration (in $\mathrm{mg} \mathrm{l}^{-1}$ ). Estimated concentrations of bioavailable $\mathrm{N}$ were determined to be $0.19 \mathrm{mg} \mathrm{l}^{-1}$ (Stn 23, representing $72 \%$ of the total N), $0.49 \mathrm{mg} \mathrm{l}^{-1}$ (Stn 84, representing $>100 \%$ of the total N) and $0.34 \mathrm{mg} \mathrm{l}^{-1}$ (Stn 357, representing $50 \%$ of the total N).

The bioluminescent reporter results suggest that $\mathrm{N}$ bioavailability, not just concentration, may have a significant impact on plankton composition in the different basins of Lake Erie. General lake circulation patterns cause water in the western basin to move into the central basin where it is well mixed in wind-driven cyclonic and anti-cyclonic gyres before entering into the eastern basin (Beletsky et al. 1999). The central basin makes up $55 \%$ of the surface area of the lake $\left(2.57 \times 10^{10} \mathrm{~m}^{2}\right)$, and at an average depth of $20 \mathrm{~m}$, the epilimnion volume would be $2.8 \times 10^{11} \mathrm{~m}^{3}$. Discharge at Niagara is $5.02 \times 10^{8} \mathrm{~m}^{3} \mathrm{~d}^{-1}$, and thus the hydraulic residence time of water in the epilimnion is about $560 \mathrm{~d}$ (18 mo). However, since this time period is longer than the period of seasonal stratification, it follows that the chemical speciation of $\mathrm{N}$ is not just a function of water column processes, but also of the processes that occur in the sediments. As such, spring turnover events not only would increase bioavailable $\mathrm{P}$ concentrations in the water column, but also bioavailable N. The onset of the spring bloom after turnover would, however, rapidly draw down the most bioavailable components. At this point (and as summer stratification fully establishes itself), highly bioavailable $\mathrm{N}$ would then be supplied to the system allochthonously through the Detroit River input into the western basin. As a result of the time required for nutrient-rich western basin water to flow to the eastern basin, these compounds would not reach the eastern basin in great abundance. As such, organisms persisting in the eastern basin would be forced to use these less-available nitrogenous compounds not drawdown by the spring bloom, to persist on regenerated $\mathrm{N}$ (from cell death), or to assimilate nitrogen from the atmospheric pool via dinitrogen fixation. Thus, the shunting of the added $\mathrm{PO}_{4}-\mathrm{P}$ into the smaller size-class of organisms (viz. picoplanktonic, 0.2 to $2 \mu \mathrm{m}$ ) is consistent with the proliferation of cyanobacteria (Downing et al. 2001) that make up the majority of the phytoplankton in this size class (Pick \& Caron 1987). While some of these cyanobacteria may be dinitrogen fixers, non-fixing cyanobacteria such as Microcystis spp. can also proliferate at low N:P ratios (Tilman 1982). Studies in the Experimental Lakes Area (e.g. Findlay et al. 1994, Hendzel et al. 1994) and Lake Kootenay (Yang et al. 1996) have previously demonstrated the principle that plankton productivity and community structure is closely linked to not only absolute levels of a potentially limiting nutrient, but also to the availability of required co-nutrients.

\section{CONCLUSIONS}

While the present study confirms the wellestablished fact that phytoplankton biomass in Lake Erie is limited by $\mathrm{PO}_{4}-\mathrm{P}$ availability, it demonstrates that the influence of total phosphorus loading is not only on biomass accumulation but also on the sizeclass composition of phytoplankton in this lake. The results clearly show that enhanced TP inputs into this system may result in markedly different plankton communities (microplankton vs nanoplankton or picoplankton) in the water column of each separate basin in Lake Erie. Other factors influencing production and community structure, such as benthic dreissenid mussel filtering activity, were not accounted for by the current study. Moreover, our results in the eastern basin support the now growing body of literature on other systems (e.g. Berman \& Chava 1999, Seitzinger \& Sanders 1999, MacGregor et al. 2001) that suggest that the chemical speciation of $\mathrm{N}$, and not just the concentration, may have a profound effect on the community structure of phytoplankton. While these results do not represent the complete picture, we hope that they stimulate other researchers to consider the type of observations required to provide accurate predictions of how the base of the food web functions in the role of providing energy for higher trophic levels in this lake.

Acknowledgements. We thank Captains J. Cloutier and M. Head, the crew of the CCGS 'Limnos', the technical operations group of Environment Canada, Dr. David Porta for assistance with the field studies, and Dr. Ralph Smith for comments on the manuscript. Supported by funds from Environment Canada (to R.A.B.), the Natural Sciences and Engineering Research Council of Canada (to M.R.T. and C.G.T.), Ohio SeaGrant (to R.M.L.M.) and the National Science Foundation (OCE-9911592 to R.M.L.M., DEB-0003069 and DEB-0129118 to S.W.W.). 


\section{LITERATURE CITED}

Azam F, Fenchel T, Field JG, Gray JS, Meyer-Reil LA, Thingstad F (1983) The ecological role of water-column microbes in the sea. Mar Ecol Prog Ser 10:257-263

Beletsky D, Saylor JH, Schwab DJ (1999) Mean circulation in the Great Lakes. J Gt Lakes Res 25:78-93

Berman T, Chava S (1999) Algal growth on organic compounds as nitrogen sources. J Plankton Res 21:1391-1421

Brittain SM, Wang J, Babcock-Jackson L, Carmichael WW, Rinehart KL, Culver DA (2000) Isolation and characterization of microcystins cyclic heptapeptide hepatotoxins from a Lake Erie strain of Microcystis aeruginosa. J Gt Lakes Res 26:241-249

Chisholm SW (1992) What limits phytoplankton growth. Oceanus 35:36-46

Cohen-Kupiec R, Gurevitz M, Zilberstein A (1993) Expression of $g \ln \mathrm{A}$ in the cyanobacterium Synechococcus sp. strain PCC 7942 is initiated from a single nif-like promoter under various nitrogen conditions. J Bacteriol 175:7727-7731

Downing JA, Watson SB, McCauley E (2001) Predicting cyanobacterial dominance in lakes. Can J Fish Aquat Sci 58:1905-1908

Elser JJ (1999) The pathway to noxious cyanobacterial blooms in lakes: the food web as the final turn. Freshw Biol 42: $537-543$

EPA (2000) Lake Erie lakewide management plan. Phosphorus revisited: emerging and other issues. Available at www.epa.gov/glnpo/lakeerie/lamp2000/frontend.pdf

Findlay DL, Hecky RE, Hendzel LL, Stainton MP, Regehr GW (1994) Relationship between $\mathrm{N}_{2}$-fixation and heterocyst abundance and its relevance to the nitrogen budget of Lake 227. Can J Fish Aquat Sci 51:2254-2266

Fuhrman JA (1999) Marine viruses and their biogeochemical and ecological effects. Nature 399:541-548

Geider RJ, LaRoche J, Greene RM, Olaizola M (1993) Response of the photosynthetic apparatus of Phaeodactylum tricornutum (Bacillariophyceae) to nitrate, phosphate, or iron starvation. J Phycol 29:755-766

Gillor O, Hadas O, Post AF, Belkin S (2002) Phosphorus bioavailability monitoring by a bioluminescent cyanobacterial sensor strain. J Phycol 38:107-115

Gillor O, Harush A, Hadas O, Post AF, Belkin S (2003) A Synechococcus PglnA:luxAB fusion for estimation of nitrogen bioavailability to freshwater cyanobacteria. Appl Environ Microbiol 69:1465-1474

GLFC (Great Lakes Fisheries Commission) (1998) Phosphorus targets achieved in Lake Erie. Press release available at www.glfc.org/pressrel/prlecpos.htm

Guildford SJ, Heckey RE (2000) Total nitrogen, total phosphorus and nutrient limitation in lakes and oceans: Is there a common relationship? Limnol Oceanogr 45: 1213-1223

Hendzel LL, Hecky RE, Findlay DL (1994) Recent changes in $\mathrm{N}_{2}$-fixation in Lake 227 in response to reduction of the N:P loading ratio. Can J Fish Aquat Sci 51:2247-2253

Hobbie JE, Daley RJ, Jasper S (1977) Use of Nuclepore filters for counting bacteria by fluorescence microscopy. Appl Environ Microbiol 33:1225-1228

Howarth RW, Marino R, Cole JJ (1988a) Nitrogen fixation in freshwater estuarine and marine ecosystems 2: biogeochemical controls. Limnol Oceanogr 33:688-701

Howarth RW, Marino R, Lane J, Cole JJ (1988b) Nitrogen fixation in freshwater estuarine and marine ecosystems 1: rates and importance. Limnol Oceanogr 33:669-687

Hutchinson GE (1961) The paradox of the plankton. Am Nat 95:137-145
Hwang SJ, Heath R (1997) Bacterial productivity and protistan bacterivory in coastal and offshore communities of Lake Erie. Can J Fish Aquat Sci 54:788 - 799

Hyenstrand P, Blomqvist P, Petterson A (1998) Factors determining cyanobacterial success in aquatic systems - a literature review. Arch Hydrobiol Spec Issues Adv Limnol 15: 41-62

IJC (International Joint Commission) (2000) Protection of the waters of the Great Lakes: final report to the Governments of Canada and the United States International Joint Commission. Available at www.ijc.org/boards/cde/interimreport/interimreporte.html

Jacoby JM, Collier DC, Welch EB, Hardy FJ, Crayton M (2000) Environmental factors associated with a toxic bloom of Microcystis aeruginosa. Can J Fish Aquat Sci 57: 231-240

Kalff J (2002) Limnology: inland water ecosystems. Prentice Hall, Upper Saddle River, NJ

Ludsin SA, Kershner MW, Blockson KA, Knight RL, Stein RA (2001) Life after death in Lake Erie: nutrient controls drive fish species richness, rehabilitation. Ecol Appl 11:731-746

MacGregor BJ, Van Mooy B, Baker BJ, Mellon M and 5 others (2001) Microbiological molecular biological and stable isotopic evidence for nitrogen fixation in the open waters of Lake Michigan. Environ Microbiol 3:205-219

Morita RY (1975) Psychrophilic bacteria. Bact Rev 39:144-167

Morris DP, Lewis WM (1992) Nutrient limitation of bacterioplankton growth in Lake Dillon, Colorado. Limnol Oceanogr 37:1179-1192

Mortimer CH (1987) Fifty years of physical investigations and related limnological studies on Lake Erie: 1928-1977. J Gt Lakes Res 13:407-435

Munawar M, Munawar IF (1996) Phytoplankton dynamics in the North American Great Lakes, Vol. 1: Lakes Ontario, Erie and St Clair. SPB Academic Publishing, Amsterdam

Murray AG, Jackson GA (1992) Viral dynamics: a model of the effects of size shape motion and abundance of singlecelled planktonic organisms and other particles. Mar Ecol Prog Ser 89:103-116

Nicholls KH, Hopkins GJ (1993) Recent changes in Lake Erie (north shore) phytoplankton: cumulative impacts of phosphorus loading reductions and the Zebra mussel introduction. J Gt Lakes Res 19:637-647

NLET (The National Laboratory for Environmental Testing) (1994) Manual of analytical methods. Environment Canada, Burlington, ON

Noble RT, Fuhrman JA (1998) Use of SYBR Green I for rapid epifluorescence counts of marine viruses and bacteria. Aquat Microb Ecol 14:113-118

Pick FR, Caron D A (1987) Picoplankton and nanoplankton biomass in Lake Ontario: relative contribution to phototrophic and heterotrophic communities. Can J Fish Aquat Sci 44:2164-2172

Price NM, Harrison GI, Hering JG, Hudson RJM, Nirel PMV, Palenik B, Morel FMM (1989) Preparation and chemistry of the artificial algal culture medium Aquil. Biol Oceanogr 6:443-461

Redfield A, Ketchum B, Richards F (1963) The influence of organisms on the composition of sea-water. In: Hill MN (ed) The sea. Academic Press, New York, p 26-77

Rippka R, DeRulles J, Waterbury JB, Herdman M, Stanier RY (1979) Generic assignments strain histories and properties of pure cultures of cyanobacteria. J Gen Microbiol 111: 1-61

Schreiter PPY, Gillor O, Post A, Belkin S, Schmid R, Bachmann TT (2001) Monitoring of phosphorus bioavailability in water by an immobilized luminescent cyanobacterial 
reporter strain. Biosen Bioelectron 16:811-818

Seitzinger SP, Sanders RW (1999) Atmospheric inputs of dissolved organic nitrogen stimulate estuarine bacteria and phytoplankton. Limnol Oceanogr 44:721-730. 99

Smith VH (1983) Low nitrogen to phosphorus ratios favor dominance by blue-green algae in lake phytoplankton. Science 221:669-671

Tilman D (1982) Resource competition and community structure. Princeton University Press, Princeton, NJ

Tilman D, Kilham SS, Kilham P (1982) Phytoplankton community ecology: the role of limiting nutrients. Annu Rev Ecol Syst 13:349-372

Twiss MR, Campbell PGC (1998) Trace metal cycling in the surface waters of Lake Erie: linking ecological and geochemical fates. J Gt Lakes Res 24:791-807

Twiss MR, Auclair JC, Charlton MN (2000) An investigation into iron-stimulated phytoplankton productivity in epipelagic Lake Erie during thermal stratification using trace metal clean techniques. Can J Fish Aquat Sci 57: 86-95

Vadstein O (1998) Evaluation of competitive ability of 2

Editorial responsibility: Fereidoun Rassoulzadegan,

Villefranche-sur-Mer, France heterotrophic planktonic bacteria under phosphorus limitation. Aquat Microb Ecol 14:119-127

Wagner F, Falkner G (2001) Phosphate limitation. In: Rai LC, Gaur JP (eds) Algal adaptation to environmental stresses - physiological, biochemical and molecular mechanisms. Springer-Verlag, New York, p 65-110

Welschmeyer NA (1994) Fluorometric analysis of chl $a$ in the presence of chl $b$ and pheopigments. Limnol Oceanogr 39: 1985-1992

Wetzel RG (2000) Freshwater ecology, changes, requirements, and future demands. Limnology 1:3-9

Wetzel R (2001) Limnology: lake and river ecosystems. Academic Press, New York

Wilhelm SW, Smith REH (2000) Bacterial carbon production in Lake Erie is influenced by viruses and solar radiation. Can J Fish Aquat Sci 57:317-326

Wilhelm SW, Suttle CA (1999) Viruses and nutrient cycles in the sea. BioScience 49:781-788

Yang JR, Pick FR, Hamilton PB (1996) Changes in the planktonic diatom flora of a large mountain lake in response to fertilization. J Phycol 32:232-243

Submitted: May 13, 2002; Accepted: March 14, 2003

Proofs received from author(s): June 10, 2003 